\title{
Penerapan Model Pembelajaran Problem Based Learning Pada Pelajaran Teknologi Jaringan Berbasis Luas (Problem Based Learning Model in Based Network Technology Learning)
}

\author{
Erwoko ${ }^{1 *}$ \\ ${ }^{1}$ Guru pada SMKN 1 Semendawai Suku III \\ Corresponding Author: Erwoko, E-mail: erwokowoko@gmail.com
}

\begin{tabular}{|c|c|}
\hline ARTICLE INFO & ABSTRACT \\
\hline $\begin{array}{l}\text { Received: } 03-11-2021 \\
\text { Accepted: } 09-12-2021 \\
\text { Volume: } 1 \\
\text { Issue: } 1 \\
\text { DOI: } \\
\text { https://doi.org/10.53754/civilofficium.v1i1.218 }\end{array}$ & \multirow{3}{*}{$\begin{array}{l}\text { This study aimed to determine the increase in student activity and } \\
\text { learning outcomes through the implementation of the Problem Based } \\
\text { Learning (PBL) model. This research is based on the fact that the average } \\
\text { score of students is deficient; as many as } 18 \text { students have not } \\
\text { completed, while } 16 \text { students have completed learning. This research is } \\
\text { classroom action research conducted in } 3 \text { cycles. The method of data } \\
\text { collection was carried out through observation. Data analysis was } \\
\text { carried out by comparing the test results in cycle } 1 \text {, cycle } 2 \text {, and cycle } 3 \\
\text { with descriptive techniques. The results of this study indicate that the } \\
\text { application of the Problem Based Learning model assisted by Edmodo in } \\
\text { the subject of Animation can improve student learning outcomes. In the } \\
\text { first cycle, it was } 47 \% \text {, in the second cycle, it increased to } 74 \% \text {, then in } \\
\text { the third cycle it increased to } 88 \% \text {, so with these data, it can be } \\
\text { concluded that the achievement of the research success criteria for } \\
\text { student learning outcomes has been achieved. Thus, it can be concluded } \\
\text { that class IX students' learning outcomes and learning activities in the } \\
\text { Lua-Based Network Technology lesson at SMKN } 1 \text { SEMENDAWAI SUKU } \\
\text { III have increased. }\end{array}$} \\
\hline KEYM & \\
\hline & \\
\hline
\end{tabular}

\section{Pendahuluan}

Para pakar pendidikan telah menjelaskan mengenai definisi pendidikan di berbagai buku, jurnal, koran, majalah, dan seterusnya yang dapat disimpulkan bahwa pendidikan secara umum dapat didefinisikan sebagai upaya sadar yang dilakukan oleh seseorang atau sekelompok orang dalam hal melakukan bimbingan, arahan, dan internalisasi ilmu dan keterampilan kepada peserta didik. Sementara objek garapannya adalah intelektual, emosional, spiritual, dan keterampilan peserta didik. Pendidikan dilakukan secara terencana, terukur, dan ter-konsep. Pada tahapan selanjutnya pendidikan dilakukan secara berjenjang dan bertahap dengan menggunakan panduan yang disebut kurikulum, di mana kurikulum tersebut berisi mengenai tujuan yang harus dicapai, metode, media, dan evaluasi pembelajaran yang tepat, dan bahan ajar atau materi pelajaran yang akan diajarkan.

Karena sedemikian pentingnya peranan pendidikan dalam kehidupan umat manusia, hingga detik ini, pendidikan masih menempati posisi yang strategis dan sentral di tengah-tengah kehidupan masyarakat. Betapa tidak? seolah hampir tidak ada pilihan lain, hanya pendidikan yang selalu digunakan untuk meningkatkan taraf hidup masyarakat di segala bidang, sekaligus mewariskan nilai-nilai moral dan kebudayaan(Wahab \& Solichin, 2008). Sehingga, darinya lahir sebuah tesis ekstrim yang mengatakan bahwa, maju atau mundurnya sebuah peradaban negara, ditentukan oleh bagaimana pendidikan yang terbangun di dalamnya.

Dalam konteks Indonesia, sesungguhnya sebagai negara ia telah menyelenggarakan pendidikan secara serius, ter-konsep, berjenjang, dan menelan biaya yang amat sangat besar. Upaya penyelenggaraan pendidikan secara serius tersebut memiliki tujuan untuk mencerdaskan kehidupan bangsa dan sekaligus memajukan peradaban dengan cara membangun kompetensikompetensi manusia Indonesia. Kompetensi-kompetensi yang dimaksud adalah kompetensi yang berhubungan dengan intelektual, emosional, spiritual dan kompetensi yang berhubungan dengan keterampilan-keterampilan. 
Namun sayangnya, dalam konteks proses penyelenggaraan pendidikan, Indonesia seolah masih belum dapat keluar dari berbagai masalah yang membelenggunya. Misalnya, hari ini berbagai sumber menginformasikan bahwa, peserta didik kita banyak sekali yang mengalami kesulitan belajar. Jika kita melakukan pengamatan mendalam terkait gejala-gejala yang terlihat, banyak di antara mereka yang terlihat malas dalam belajar, kurang fokus, tidak mendengarkan guru, asik bermain sendiri, kurang aktif dalam diskusi, tidak mau bertanya jika belum paham, cenderung acuh dengan materi pelajaran, dan sebagainya. Antusiasme peserta didik yang rendah dalam belajar tersebut menurut informasi lantaran proses kegiatan belajar di ruang-ruang kelas yang bisa dibilang, stagnan, kurang inovatif, dan sangat terkesan membosankan.

Merespon problem pendidikan tersebut, kemudian para pakar pendidikan bergegas dan berbondong-bondong untuk membuat berbagai macam metode pembelajaran yang sekiranya dapat membuat kelas menjadi hidup, peserta didik dapat aktif dan partisipatif, inovatif, kreatif, sekaligus menyenangkan. Upaya tersebut semata-mata untuk membangun sebuah iklim pembelajaran yang hidup, aktif, dan menyenangkan. Harapannya, ketika proses pembelajaran dapat berjalan dengan aktif dan menyenangkan, hasil pembelajaran pun kemudian menjadi lebih meningkat. Mengingat banyaknya model pembelajaran yang telah dikembangkan oleh para pakar, guru diharuskan memiliki kompetensi untuk memilih metode yang tepat sekaligus guru juga dituntut untuk dapat menjalankannya. (Amri \& Sofan, 2013, p. 5)

Salah satu faktor yang menentukan keberhasilan pembelajaran adalah model pembelajaran yang dibangun di dalam kelas. Urgensi metode dan model pembelajaran yang dibangun di dalam kelas tersebut, bahkan pemerintah telah mengeluarkan aturan perundangan yang mengatur tentang implementasi metode dan model pembelajaran. Aturan perundangan tersebut termaktub dalam Peraturan Menteri Pendidikan dan Kebudayaan Republik Indonesia Nomor 65 Tahun 2013 mengenai standar proses pendidikan dasar dan menengah, yakni: “Dalam rangka menguatkan pendekatan ilmiah (scientific), tematik terpadu (tematik antar mata pelajaran) dan tematik (dalam suatu mata pelajaran) perlu diimplementasikan pembelajaran berbasis penyingkapan atau penelitian (discovery/inquiry learning). Sedangkan untuk memberikan dorongan bagi kompetensi siswa dalam menghasilkan karya kontekstual, baik individual ataupun kelompok amat disarankan memakai pendekatan pembelajaran yang menghasilkan karya berbasis pemecahan masalah (project-based learning).

Oleh sebab itu, dalam mengajar dan mendidik, guru hendaknya menyelaraskannya dengan aturan perundangan yang berlaku serta karakteristik dari materi ajar yang akan disampaikan kepada peserta didik (Rusman, 2013, p. 229) mengatakan bahwasannya, guru harus dapat memilih, menggunakan, dan bahkan dapat menciptakan metode pembelajaran yang bisa mendorong spirit peserta didik sehingga mereka mau aktif dalam belajar. Sebab, dengan pembelajaran yang melibatkan keaktifan siswa maka siswa akan mudah memahami materi. Terdapat banyak sekali metode atau model pembelajaran yang telah dikembangkan oleh para pakar pendidikan. Salah satu model pembelajaran yang memiliki potensi besar mampu merangsang daya nalar atau keterampilan berpikir peserta didik dalam menyelesaikan berbagai masalah adalah model pembelajaran berbasis masalah (Problem Based Learning).

Dalam perspektif (Huda, 2013, p. 271) pembelajaran berbasis masalah mempunyai karakteristik, misalnya diawali dengan guru yang memberi masalah kepada peserta didik, di mana masalah-masalah yang disajikan diambil dari fenomena-fenomena yang terjadi dalam kehidupan nyata, kemudian peserta didik mempelajari masalah yang disajikan dan ditentukan rumusan masalahnya, kemudian siswa mengerahkan segenap daya nalarnya untuk menguraikan dan memecahkan masalahnya. Pada titik ini guru lebih cenderung menjadi fasilitator yang baik yang dengan sigap membantu dan mengarahkan peserta didik jika dibutuhkan.

Tidak ada perbedaan yang esensial dengan Miftahul, Sari dan Nasikh juga mengatakan bahwa Problem Based Learning pada satu sisi memang di konstruksi supaya guru dengan mudah menginformasikan secara detail kepada peserta didik. Namun, di sisi lain, PBL ini juga di konstruksi untuk mengembangkan daya nalar peserta didik sehingga mereka memiliki kecakapan dalam menyelesaikan masalah dan tidak selalu bergantung pada guru. Dengan kata lain, guru tidak lagi menjadi pusat kebenaran tunggal dan menghegemoni kelas. Jika pembelajaran seperti yang telah dijelaskan tersebut dapat mewujud nyata di ruang-ruang kelas kita, maka output pendidikan kita akan menghasilkan sumber daya manusia yang cerdas, cakap, kreatif, inovatif, dan siap menyongsong masa depan yang penuh dengan tantangan.

Paradigma berpikir yang mengatakan bahwa materi pelajaran harus dihafal serta metode ceramah dan hafalan, selama ini masih mendominasi gaya pembelajaran di sekolah SMK Mendawai Suku III. Pembelajaran di sekolah ini juga masih berfokus pada guru (teacher) sebagai sumber kebenaran pengetahuan tunggal dan utama. Melihat dunia yang terus berkembang dan menuntut perubahan di sana sini, maka penyelenggaraan pendidikan pun harus terus di modernisasi sesuai dengan kerangka modernitas. Berbagai macam, strategi, model, dan model pembelajaran harus terus dikembangkan dengan sebaik mungkin. Berdasarkan latar belakang di atas, maka penelitian tindakan kelas mengenai Penerapan Model Pembelajaran Problem Based Learning Pada Pelajaran Teknologi Jaringan Berbasis Luas menjadi penting untuk dilakukan. 


\section{Kajian Literatur}

Para pakar telah mendefinisikan mengenai istilah Penelitian Tindakan Kelas (PTK) ini secara berbeda-beda secara redaksional namun menemukan kesamaannya pada tataran substansial. Misalnya menurut perspektif Mulyasa, Penelitian Tindakan Kelas (PTK) atau juga yang sering disebut dengan penelitian tindakan (action research) adalah penelitian yang dilakukan karena proses pembelajaran di kelas terjadi masalah dan kemudian penelitian tersebut dilakukan untuk melakukan perbaikan atas proses serta hasil belajar sekelompok peserta didik (Suyanto, 2016). Sedangkan dalam perspektif (Arikunto, 2006) Penelitian Tindakan Kelas diartikan sebagai sebuah observasi tindakan pembelajaran yang secara sengaja dilakukan dalam sebuah kelas secara bersama-sama. Sementara Penelitian tindakan kelas (classroom action research) adalah penelitian tindakan (action research) yang dilakukan di kelas (Legiman, 2015).

Berdasarkan definisi diatas dapat disimpulkan bahwa penelitian tindakan kelas merupakan penelitian yang sifatnya memperbaiki atau reparatif, maksudnya penelitian ini dilakukan untuk melakukan perbaikan proses pembelajaran supaya peserta didik dapat meraih hasil pembelajaran secara optimal. Penelitian tindakan kelas dilakukan diawali dengan adanya permasalahan dalam proses pembelajaran di kelas lalu proses pembelajaran tersebut diperbaiki supaya peserta didik dapat memperoleh hasil yang diharapkan. Sedangkan dalam pandangan Holins, langkah-langkah yang harus dilakukan dalam penelitian tindakan kelas diawali dengan melakukan perencanaan tindakan (Planning), kemudian menerapkan tindakan (action), melakukan observasi dan melakukan evaluasi proses serta hasil tindakan (Observation and evaluation). Sedangkan prosedur kerjanya meliputi empat komponen, yakni perencanaan (planning), pelaksanaan (acting), pengamatan (observing), dan refleksi(reflecting), dan seterusnya sehingga terjadinya perbaikan atau peningkatan yang dicanangkan dapat terwujud (kriteria keberhasilan) (Kustian, Abdurakhman, \& Firmansyah, 2018).

Terdapat sejumlah pengertian belajar dalam perspektif para pakar. Pengertian dari pakar tersebut secara redaksional memang terlihat berbeda-beda, namun secara substansi sesungguhnya menemui kesamaannya. Misalnya menurut Sardiman, belajar adalah kegiatan atau aktivitas yang bertujuan untuk mengubah perilaku atau performa di mana aktivitasnya antara lain membaca, mengamati, mendengarkan, meniru, dan lain sebagainya (Sardiyanah, 2020). Belajar juga disebut sebagai serangkaian aktivitas jiwa raga, psiko-fisik untuk mengembangkan pribadi manusia seutuhnya, yang berarti menyangkut unsur cipta, rasa dan karsa, ranah cognitive, affective, dan psychomotor (Sardiyanah, 2020).

Skinner dalam (McLeod Saul, 2018) juga mendefinisikan mengenai pengertian belajar. Mereka menyebut bahwa belajar merupakan suatu perilaku. Logika yang dibangun sangat sederhana, yaitu, Ketika seseorang belajar, maka kemampuannya serta responnya akan membaik, ditinjau dari semua sisi. Namun akan menjadi sebaliknya, ketika seseorang enggan belajar yang terjadi adalah kapasitas dan responnya akan mengalami keterbelakangan. Sementara dalam pandangan Gagne dalam (Djamarah \& Bahri, 2008) adalah aktivitas yang amat sangat kompleks. Sementara wujud dari hasil belajar adalah kapasitas, kemampuan, dan kapabilitas. Ketika seseorang telah mengalami proses belajar, makai akan mempunyai keterampilan, pengetahuan, sikap, dan nilai.

Dari penyataan diatas dapat disimpulkan bahwa, belajar dan pembelajaran adalah sebuah usaha untuk melakukan perubahan dalam kepribadian individu dan perubahan tersebut tampak dalam bentuk peningkatan kualitas dan kuantitas tingkah laku individu seperti kecakapan, pengetahuan, sikap, kebiasaan, keterampilan, pola pikir dan kemampuankemampuan yang lain.

Terdapat beberapa prinsip belajar yang harus ditegakkan oleh guru sebagai fasilitator kegiatan Pendidikan dan pembelajaran. Dalam konteks ini, guru sebagai subjek yang bertanggung jawab atas jalannya pembelajaran dan Pendidikan harus benarbenar melakukan penegakan prinsip-prinsip pembelajaran sekaligus melakukan control. Namun menurut para pakar, guru diwajibkan untuk membuat sejumlah prinsip belajar yang bisa diimplementasikan di berbagai situasi dan kondisi yang berbeda-beda dan oleh setiap peserta didik secara personal. Beberapa prinsip-prinsip belajar yang relatif umum yang dapat dipakai sebagai dasar dalam upaya pembelajaran menurut (Dahar, 2006) antara lain: (a) perhatian dan motivasi, (b) keaktifan, (c) keterampilan langsung/berpengalaman, (d) pengulangan, (e) tantangan, (f) balikan dan penguatan, (g) perbedaan individual. Sementara secara lebih rinci sesungguhnya tujuan dari pembelajaran adalah untuk, perubahan perilaku, mengubah kebiasaan, mengubah keterampilan, Menambah pengetahuan dalam berbagai bidang ilmu.

Hasil belajar yaitu sesuatu yang diperoleh atau yang dicapai oleh seseorang atau individu setelah seseorang tersebut melakukan kegiatan belajar secara serius. Hasil belajar seseorang memiliki wujud yakni berubahnya kompetensi-kompetensi seseorang dalam aspek kognitif, afektif dan psikomotorik. Pada umumnya, hasil belajar dipengaruhi oleh beberapa faktor(1) materi pelajaran, (2) lingkungan peserta didik, (3) sarana dan prasarana, (4) kondisi peserta didik, dan (5) proses pembelajaran. (Maufur, 2009) menjelaskan mengenai sejumlah hal yang berpengaruh terhadap hasil belajar. Sejumlah faktor 
tersebut yaitu faktor internal dan faktor eksternal. Faktor internal adalah faktor yang mempengaruhi hasil belajar individu yang datangnya dari dalam diri peserta didik tersebut. Sementara faktor eksternal adalah faktor yang berasal dari luar diri peserta didik atau sering disebut dengan factor lingkungan. Sedangkan dalam perspektif (Sanjaya, 2009, p. 52) banyak faktor yang mempengaruhi hasil belajar. Misalnya, faktor guru atau pendidik, faktor peserta didik, fasilitas belajar atau sarana, media, dan faktor lingkungan Pendidikan yang melingkupi.

Para ahli memiliki pandangan yang berbeda-beda mengenai definisi dari Pembelajaran Berbasis Masalah. Namun perbedaanya hanya pada tataran redaksional saja dan menemukan kesamaan dalam tataran substansi. Pengertianpengertian tersebut misalnya, menurut Agus Suprijono, pembelajaran berbasis masalah yaitu model pembelajaran di mana peserta didik di setting untuk dapat menemukan sesuatu atau discovery learning. Karenanya, peserta didik didukung supaya dapat belajar secara aktif dengan konsep-konsep dan prinsip-prinsip (Hairani, 2018). Menurut Wina Sanjaya, pembelajaran berbasis masalah dapat diartikan sebagai serangkaian kegiatan pembelajaran di mana pembelajaran tersebut memberikan penekanan pada proses penyelesaian masalahyang dihadapi secara ilmiah (Sanjaya, 2006).

Dari sejumlah definisi yang sudah disampaikan para pakar tersebut dapat diambil kesimpulan bahwa pembelajaran berbasis masalah adalah model pendekatan pembelajaran yang memberikan penekanan khusus pada aktivitas peserta didik baik aktivitas berfikir, bersikap serta berkarya dalam menguraikan dan menyelesaikan segala masalah yang dihadapi. Karena itu tidak mengherankan jika model pembelajaran berbasis masalah (Problem Based Learning), disebut sebagai salah satu pembelajaran inovatif yang bisa menciptakan suasana pembelajaran yang aktif bagi peserta didik.

\section{Metodologi}

Penelitian ini bertujuan untuk menjelaskan pembelajaran kooperatif model Problem Based Learning (PBL) pada siswa. Penelitian ini bersifat deskriptif karena hanya mendeskripsikan tentang keadaan model pembelajaran Problem Based Learning (PBL) yang diterapkan pada mata pelajaran Teknologi Jaringan Berbasis Luas di SMKN I Semendawai Suku III. Pendekatan kualitatif ini bersifat naturalistik karena penelitian ini memang terjadi secara alamiah, apa adanya dalam situasi yang tidak dimanipulasi keadaan dan kondisinya, menekankan pada deskripsi secara alami. Pengambilan data atau penjaringan fenomena dilakukan dari keadaan yang sewajarnya ini dikenal dengan sebutan pengambilan data secara alami dan natural.

\section{Hasil dan pembahasan}

Pada kegiatan pembelajaran yang telah dilaksanakan pada siklus I, II, dan III telah dilakukan pengambilan data dengan evaluasi untuk mengetahui hasil belajar. Berdasarkan data hasil penelitian yang telah dilakukan pada kelas IX mata pelajaran Jaringan Berbasis Luas Animasi di SMKN 1 Semendawai Suku III, terdapat adanya peningkatan hasil belajar dengan menerapkan model pembelajaran Problem Based Learning. Berikut merupakan hasil penelitian yang telah dilaksanakan pada siklus I, II, dan III:

Tabel 1 Hasil Belajar siswa siklus I, II, dan III

\begin{tabular}{lllll}
\hline NO & NAMA & SIKLUS I & SIKLUS II & SIKLUS III \\
\hline 1 & HADI PURNOMO & 70 & 80 & 80 \\
2 & ROHMAT & 70 & 80 & 80 \\
3 & MAULANA YUDIAN & 90 & 90 & 90 \\
4 & AMIRUL ANSOR & 80 & 80 & 80 \\
5 & AMPUH PAMBUDI & 70 & 80 & 80 \\
6 & HAWIN MUHTAROM & 80 & 90 & 90 \\
7 & ALAN BUDI H. & 60 & 70 & 70 \\
8 & NISA BAROKAH & 80 & 80 & 80 \\
9 & YOSI WULANDARI & 80 & 80 & 80 \\
10 & RUSMINING & 50 & 60 & 60 \\
11 & SAUQI FUTAQI & 70 & 70 & 80 \\
12 & ENDIK WASKITO & 100 & 100 & 100 \\
13 & ENDIK WAHYUDI & 70 & 90 & 90 \\
\hline
\end{tabular}




\begin{tabular}{|c|c|c|c|c|}
\hline NO & NAMA & SIKLUS I & SIKLUS II & SIKLUS III \\
\hline 14 & BAGUS ANWAR & 90 & 90 & 90 \\
\hline 15 & AHMAT SULTON & 90 & 100 & 100 \\
\hline 16 & FATA ASYROFI YAHYA & 50 & 80 & 80 \\
\hline 17 & AHMAD AFIF & 60 & 80 & 80 \\
\hline 18 & WENI TRIA PUTRI & 70 & 70 & 80 \\
\hline 19 & KHOIROTUNNIKMAH & 90 & 90 & 90 \\
\hline 20 & FARADISYA EKAPTI & 70 & 90 & 90 \\
\hline 21 & NUR AZIZAH & 80 & 100 & 100 \\
\hline 22 & GALUH SITARESMI & 80 & 80 & 80 \\
\hline 23 & ABEL MONIKA & 70 & 80 & 80 \\
\hline 24 & BILQINAYA ROBI & 80 & 80 & 80 \\
\hline 25 & NADA YUDANTA & 90 & 100 & 100 \\
\hline 26 & NAJELA YUMNA & 70 & 70 & 80 \\
\hline 27 & BERLIAN PANCARANI & 50 & 60 & 70 \\
\hline 28 & LUKMAN HAKIM & 50 & 60 & 70 \\
\hline 29 & GALIH AKBAR & 80 & 80 & 80 \\
\hline 30 & SAKURIANA & 70 & 80 & 80 \\
\hline 31 & BANI AHMAD & 50 & 70 & 80 \\
\hline 32 & SYUKRI FAUZI & 70 & 70 & 80 \\
\hline 33 & MANOHARA & 90 & 100 & 100 \\
\hline \multirow[t]{7}{*}{34} & MELISA CAHYANI & 80 & 90 & 90 \\
\hline & NILAI TERTINGGI & 100 & 100 & 100 \\
\hline & NILAI TERENDAH & 50 & 60 & 60 \\
\hline & RATA-RATA & 73,5 & 81,4 & 83,5 \\
\hline & JUMLAH SISWA TIDAK TUNTAS & 18 & 9 & 4 \\
\hline & JUMLAH SISWA TUNTAS & 16 & 25 & 30 \\
\hline & PERSENTASE KETUNTASAN (\%) & $47 \%$ & $74 \%$ & $88 \%$ \\
\hline
\end{tabular}




\section{GRAFIK PERSENTASE KETUNTASAN}

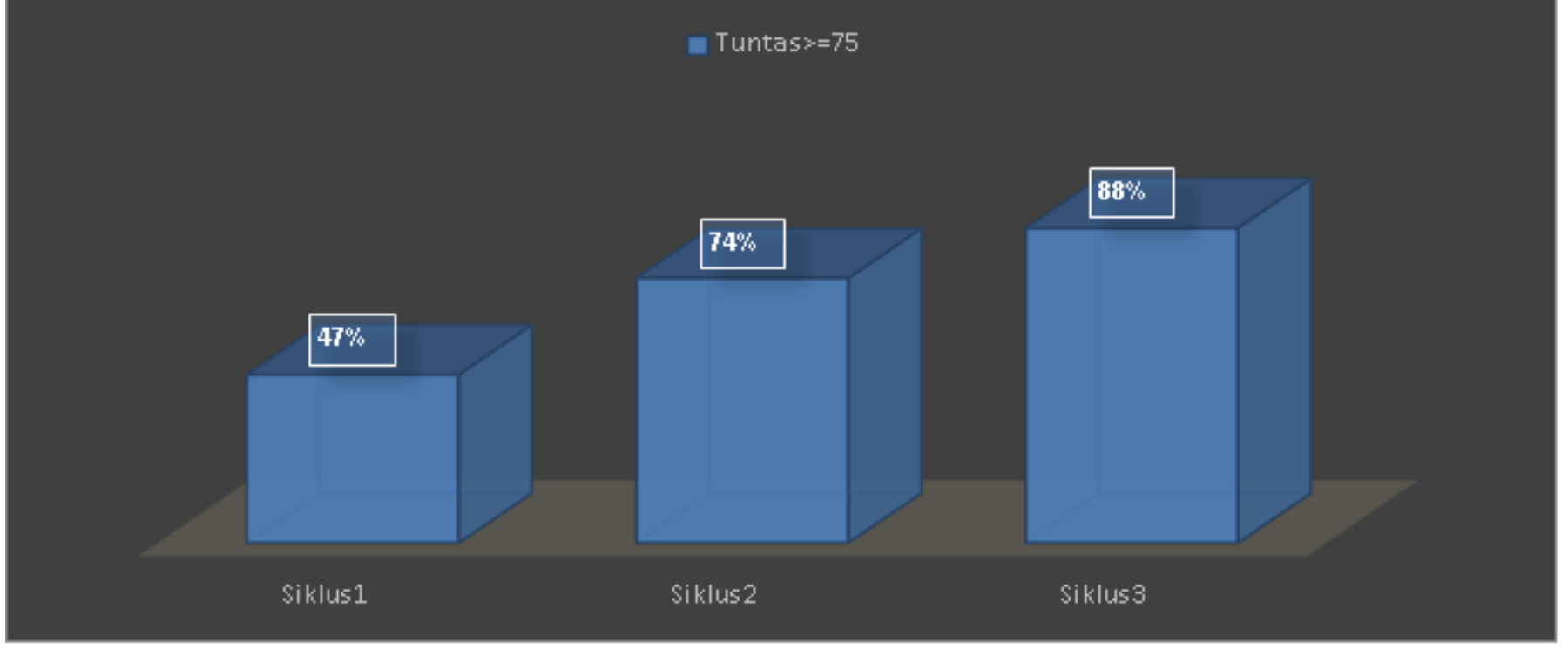

Gambar 1. Persentase Ketuntasan Hasil Belajar Siswa

Berdasarkan data diatas dapat disimpulkan bahwa ketuntasan hasil belajar siswa pada siklus I yaitu $47 \%$ dengan jumlah siswa yang tuntas sebanyak 16 siswa. Dalam pelaksanaan siklus I belum mencapai kriteria ketuntasan sehingga dilanjutkan pada siklus II dengan persentase hasil belajar siswa mencapai $74 \%$ dengan jumlah siswa yang tuntas sebanyak 25 siswa, kemudian dilanjutkan ke siklus III dengan hasil belajar mencapai $88 \%$ dengan jumlah siswa yang tuntas sebanyak 30 siswa. Dari hasil data yang diperoleh dari siklus I, II, dan III, dapat diketahui bahwa penerapan model pembelajaran Problem Based learning berbantuan Edmodo pada mata pelajaran Animasi dapat meningkatkan hasil belajar siswa. Pada siklus I sebesar $47 \%$, pada siklus II meningkat menjadi $74 \%$, kemudian pada siklus III meningkat menjadi $88 \%$, sehingga dengan data tersebut dapat disimpulkan bahwa ketercapaian kriteria keberhasilan penelitian hasil belajar siswa telah tercapai.

\section{Simpulan}

Berdasarkan hasil temuan dan pembahasan yang telah dikemukakan, dapat ditarik dua kesimpulan. Pertama, pelaksanaan model pembelajaran Problem Based Learning pada kelas IX mata pelajaran Jaringan Berbasis Luas Animasi di SMKN 1 Semendawai Suku III sudah berjalan lancar. Hal ini ditandai dengan peningkatan keaktifan siswa yang sebelumnya cenderung pasif setelah diterapkan model pembelajaran ini mulai mengalami peningkatan dalam ke-aktif-annya di dalam kelas saat pembelajaran sedang berlangsung. Kedua, penerapan model pembelajaran Problem Based Learning pada kelas IX mata pelajaran Jaringan Berbasis Luas Animasi di SMKN 1 Semendawai Suku III dapat meningkatkan hasil belajar siswa. Hal ini dapat diketahui dari hasil belajar siswa yang mengalami peningkatan setelah diadakan tindakan siklus I, II dan siklus III. Sebelum diadakan penelitian nilai rata-rata siswa sangat rendah yaitu sebanyak 18 siswa belum tuntas, sedangkan 16 siswa tuntas belajar. Hasil belajar siswa pada siklus II mengalami sedikit peningkatan, yaitu nilai rata-rata kelas 81,4 dan daya serap klasikal 73,5\% dan yang belum tuntas 9, kemudian dilanjutkan ke siklus III dan mengalami peningkatan yang lebih baik lagi, yaitu dengan nilai rata-rata kelas 83,5 dan daya serap klasikal 88,2\% dengan kriteria tuntas belajar sebanyak 34 siswa.

\section{Daftar Pustaka}

[1] Amri, \& Sofan. (2013). Pengembangan dan Model Pembelajaran dalam Kurikulum. Jakarta: Prestasi Pustaka Raya.

[2] Arikunto, S. (2006). Prosedur Penelitian Suatu Pendekatan Praktik. Jakarta: Rineka Cipta.

[3] Dahar, R. W. (2006). Teori-Teori Belajar dan Pembelajaran. Bandung: Erlangga.

[4] Djamarah, \& Bahri, S. (2008). Psikologi Belajar. Jakarta: Rineka Cipta.

[5] Hairani, E. (2018). Pembelajaran Sepanjang Hayat Menuju Masyarakat Berpengetahuan. TAJDID: Jurnal Pemikiran Keislaman Dan Kemanusiaan, 2(1). https://doi.org/10.52266/tadjid.v2i1.107

[6] Huda, M. (2013). Model-Model Pengajaran dan Pembelajaran. Yogyakarta: Pustaka belajar.

[7] Kustian, E., Abdurakhman, O., \& Firmansyah, W. (2018). STRATEGI PEMASARAN JASA PENDIDIKAN DALAM MENINGKATKAN KUANTITAS SISWA. TADBIR MUWAHHID, 2(2). https://doi.org/10.30997/jtm.v2i2.1176 
[8] Legiman. (2015). Penelitian Tindak Kelas (PTK). LPMP Yogyakarta, 1(1).

[9] Maufur, H. F. (2009). Sejuta Jurus Mengajar Mengasikkan. Semarang: Sindur Press.

[10] McLeod Saul. (2018). B.F. Skinner :Operant Conditioning. Simply Psychology, (1948).

[11] Rusman. (2013). Model-Model Pembelajaran Mengembangkan Profesionalisme Guru. Jakarta: Raja Grafindo Persada.

[12] Sanjaya, W. (2006). Strategi Pembelajaran. Jakarta: Raja Grafindo Persada.

[13] Sanjaya, W. (2009). Kurikulum dan Pembelajaran: Teori dan Praktik Pengembangan, KTSP Jakarta. In Kencana Prenada Media Group.

[14] Sardiyanah, S. (2020). BELAJAR DAN FAKTOR YANG MEMPENGARUHINYA. Jurnal Al-Qalam: Jurnal Kajian Islam \& Pendidikan, 7(1). https://doi.org/10.47435/al-qalam.v7i1.187

[15] Suyanto, S. (2016). Penelitian Tindakan Kelas (Ptk). Journal of Chemical Information and Modeling, 1(September).

[16] Wahab, A., \& Solichin. (2008). Analisis Kebijaksaan dari formulasi ke implementasi kebijaksanaan negara. Jakarta: Bumi Aksara.

@ $\odot \otimes$

(C) 2021 by the authors. Submitted for possible open access publication under the terms and conditions of the Creative Commons Attribution-NonCommercial 4.0 International License (CC BY NC) license (https://creativecommons.org/licenses/by-nc/4.0/). 